\title{
New insights into nocturnal nucleation
}

\author{
I. K. Ortega ${ }^{1}$, T. Suni ${ }^{1}$, M. Boy ${ }^{1}$, T. Grönholm ${ }^{1}$, H. E. Manninen ${ }^{1}$, T. Nieminen ${ }^{1}$, M. Ehn ${ }^{1}$, H. Junninen ${ }^{1}$, H. Hakola ${ }^{2}$, \\ H. Hellén ${ }^{2}$, T. Valmari ${ }^{3}$, H. Arvela ${ }^{3}$, S. Zegelin ${ }^{4}$, D. Hughes ${ }^{4}$, M. Kitchen ${ }^{4}$, H. Cleugh ${ }^{4}$, D. R. Worsnop ${ }^{1}$, M. Kulmala ${ }^{1}$, \\ and V.-M. Kerminen ${ }^{1}$ \\ ${ }^{1}$ Division of Atmospheric Sciences, Department of Physics, P.O. Box 64, 00014 University of Helsinki, Finland \\ ${ }^{2}$ Finnish meteorological institute, Air Chemistry Laboratory, P.O. Box 503, 00101 Helsinki, Finland \\ ${ }^{3}$ STUK, Radiation and Nuclear Safety Authority, P.O. Box 14, 00881 Helsinki, Finland \\ ${ }^{4}$ CSIRO - Commonwealth Scientific and Industrial Research Organisation, Marine and atmospheric research, P.O. Box 3023, \\ ACT 2604, Canberra, Australia
}

Correspondence to: I. K. Ortega (ismael.ortegacolomer@helsinki.fi)

Received: 6 May 2011 - Published in Atmos. Chem. Phys. Discuss.: 30 November 2011

Revised: 27 March 2012 - Accepted: 21 April 2012 - Published: 15 May 2012

\begin{abstract}
Formation of new aerosol particles by nucleation and growth is a significant source of aerosols in the atmosphere. New particle formation events usually take place during daytime, but in some locations they have been observed also at night. In the present study we have combined chamber experiments, quantum chemical calculations and aerosol dynamics models to study nocturnal new particle formation. All our approaches demonstrate, in a consistent manner, that the oxidation products of monoterpenes play an important role in nocturnal nucleation events. By varying the conditions in our chamber experiments, we were able to reproduce the very different types of nocturnal events observed earlier in the atmosphere. The exact strength, duration and shape of the events appears to be sensitive to the type and concentration of reacting monoterpenes, as well as the extent to which the monoterpenes are exposed to ozone and potentially other atmospheric oxidants.
\end{abstract}

\section{Introduction}

In 2007, the Intergovernmental Panel on Climate Change (IPCC) revised their prediction of the global average temperature increase during the next century from 1.4-5.8 to 1.1$6.4^{\circ} \mathrm{C}$. A major factor behind the large uncertainty range in this prediction is the general lack of understanding on the role of aerosol particles in the Earth's climate system (e.g. Myhre, 2009; Quaas et al., 2009; Hansen et al., 2011). Since the lifetime of atmospheric aerosol particles is only a few days, the climatic and other effects by these particles depend strongly on the magnitude and distribution of their sources. An important, yet poorly-quantified, source of atmospheric aerosol particles is their formation by nucleation from gaseous precursor vapors. This phenomenon has been observed to take place almost everywhere in the Earth's atmosphere (Kulmala et al., 2004; Manninen et al., 2010) and it has been the subject of several global modeling studies during the last few years (e.g. Spracklen et al., 2006; Makkonen et al., 2009; Kazil et al., 2010; Yu et al., 2010).

The exact molecular mechanism(s) and participating vapors causing atmospheric nucleation events have not yet been resolved. Nucleation tends to occur preferably during daytime, which refers to a photochemical origin of this phenomenon (e.g. Kulmala and Kerminen, 2008). In many locations, however, also nighttime nucleation has been observed (e.g. Wiedensohler et al., 1997; Vehkamäki et al., 2004; Junninen et al., 2008; Lee et al., 2008; Suni et al., 2008; Svenningsson et al., 2008). Compared with daytime nucleation events, nocturnal events have been studied to a very limited extent, even though this phenomenon might provide us new insight into atmospheric nucleation mechanisms.

Among the observations reported so far, the most intense and frequent nocturnal nucleation events were observed at Tumbarumba in Australia (Suni et al., 2008). During the Tumbarumba measurement campaign that took place between 2005 and 2007, 32\% of the nucleation events were observed during the night time (Suni et al., 2008). It was hypothesized that such intense nocturnal events were due to the 
unusually high concentrations of radon and/or the presence of Eucalypt trees. In order to evaluate the possible role of radon and Eucalypt tree emissions in nucleation events, we carried out a series of chamber experiments (Ortega et al., 2009). These experiments ruled out the participation of radon and eucalyptol (one of the most abundant volatile organic compound (VOC) in Tumbarumba) in nocturnal nucleation events, leaving the question of what is behind such events open.

In this manuscript, our main goal is to get new insight into nocturnal new particle formation in environments dominated by biogenic VOC emissions, such as forested areas. We will focus on the ozone chemistry of monoterpenes, keeping in mind that the nitrate radical might be equally important night-time oxidant in air masses containing high levels of nitrogen oxides (e.g. Brown et al., 2011). The specific questions we are aiming to address include (i) how large ozone and monoterpene concentrations are needed to initiate nocturnal nucleation, (ii) how this process varies with different monoterpenes and experimental conditions, and (iii) are we able to produce, and under which conditions, the different types of nocturnal nucleation events observed at Tumbarumba and elsewhere. We concentrate on three monoterpenes abundant in both Tumbarumba and boreal forest environments: limonene, $\alpha$-pinene and $\Delta^{3}$-carene. We approach the problem by performing a series of chamber experiments by making quantum chemical calculations and aerosol dynamic model simulations.

\section{Materials and methods}

We carried out an intensive experimental campaign between 29 October and 17 November 2008 at the Finnish Radiation Protection Centre in Helsinki. During this campaign, we tested three different monoterpenes: $\alpha$-pinene $(>99 \%$, Fluka), $\Delta^{3}$-carene (95\%, Sigma-Aldrich) and limonene (98\% Sigma-Aldrich). All the experiments were carried out in dark conditions and in the presence of ozone.

\subsection{Experimental setup}

We conducted the experiments in a $14 \mathrm{~m}^{3}$ isolated room that was ventilated with an air flow of $201 \mathrm{~min}^{-1}$. The temperature and relative humidity inside the room were monitored using a Delta OHM DO 9847 logger with capacitive Mk33 and K-type thermocouple sensors. $\mathrm{O}_{3}$ and $\mathrm{SO}_{2}$ concentrations were measured with a Dasibi Model 1008-RS UVabsorption ozone photometer and a pulsed fluorescence $\mathrm{SO}_{2}$ analyzer model 43C (Thermo Environmental Instruments, Inc.); $\mathrm{NO}_{\mathrm{x}}, \mathrm{NO}$ and $\mathrm{NO}_{2}$ concentrations where measured with a Thermo Scientific, Model 42i-TL analyzer.

We used a Neutral cluster and Air Ion Spectrometer (NAIS) to measure the mobility distribution of both negative and positive air ions in the diameter range of $0.8-40 \mathrm{~nm}$
(Kulmala et al., 2007; Manninen et al., 2009, 2010). The instrument comprises two parallel units (Differential Mobility Analyzers, DMAs) with opposite polarities. In addition to the ion size distribution, the NAIS measures the mobility size distributions of neutral and charged aerosol particles and sub$3 \mathrm{~nm}$ clusters. The time resolution for a single measurement cycle, consisting of ion, total particle and background signal measurements, was $5 \mathrm{~min}$ in our experiments. In parallel with the NAIS, we used a Differential Mobility Particle Sizer (DMPS) to measure the particle number size distribution in the $10-1000 \mathrm{~nm}$ diameter range. The DMPS uses a Hauketype DMA $(28.0 \mathrm{~cm})$, CPC (TSI 3010) as a particle detector, closed loop sheath flow arrangements (Jokinen and Mäkelä, 1996) and the same radioactive Krypton- 85 beta neutralizer. The complete size distribution is obtained in a 10-min time resolution by changing the classifying voltage of the DMA. An example of this DMPS system has been described in more detail by Aalto et al. (2001). The total aerosol number concentration was calculated from the measured particle number size distribution.

Concentrations of volatile organic compounds ( $\alpha$-pinene, $\Delta^{3}$-carene, and limonene) were determined using TenaxTA/Carbopack-B adsorbent tubes. We pumped air from the room through the tubes for $10 \mathrm{~min}$ with a constant flow rate of $100 \mathrm{ml} \mathrm{min}^{-1}$. The adsorbent tubes were analysed using a thermodesorption instrument (Perkin-Elmer TurboMatrix 650 ATD) connected to a gas chromatograph-mass spectrometer (Perkin-Elmer Clarus 600) with DB-5 ms column (50 m, i.d. $0.25 \mathrm{~mm}$ ).

The chemical composition of the aerosol particles larger than $\sim 50 \mathrm{~nm}$ diameter was measured with an Aerodyne aerosol mass spectrometer (C-TOF-AMS, Canagaratna et al., 2007). The AMS uses thermal vaporization and electron impact ionization for measuring the non-refractory constituents of the aerosol. The purpose of the AMS in this study was mainly to confirm the presence and amount of organic compounds in aerosol particles during the experiments with different precursors.

Monoterpenes were introduced into the chamber by two different methods. In the so-called direct method, we put an open container with liquid monoterpene into the chamber, and used a fan inside the chamber to make the gas distribution as homogeneous as possible. In this way, we were able to get a high monoterpene concentration inside the chamber. The second method was based on putting liquid monoterpene in a flask outside the chamber and then flowing air through the flask. The flask was connected with the chamber by using a Teflon tube trough the wall. This method allowed us to control the flux of monoterpenes into the chamber via the control of the air flow rate trough the flask.

\subsection{Growth rates and formation rates}

We calculated the growth rates of nucleated particles with the method by Hirsikko et al. (2005). First, we determined 
the timing of the maximum particle number concentration in each size fractions measured by the NAIS. Then, a linear function was fitted into these points in three size ranges: $<3 \mathrm{~nm}, 3-7 \mathrm{~nm}$ and $7-20 \mathrm{~nm}$.

The formation rate of negative and positive 2-nm particles, $J_{2}^{ \pm}$, was calculated via the following formula (e.g. Kulmala et al., 2007):

$J_{2}^{ \pm}=\frac{d N_{2-3}^{ \pm}}{d t}+\mathrm{CoagS} \cdot N_{2-3}^{ \pm}+\frac{\mathrm{GR}_{<3}}{1 \mathrm{~nm}} \cdot N_{2-3}^{ \pm}+\alpha \cdot N_{2-3}^{ \pm} \cdot N_{<3}^{\mp}$,

Here, $N_{2-3}^{ \pm}$is the number concentration of ions in the diameter range $2-3 \mathrm{~nm}$ measured by the NAIS. The first term on the right hand side of Eq. (1) represents the observed rate of change of the ion number concentration, the second term is the loss of ions into larger particles by coagulation, the third term is condensational growth out of the $2-3 \mathrm{~nm}$ size range, and the last term represent ion-ion recombination that produces neutral particles. We should also take into account the charging of neutral particles in the $2-3 \mathrm{~nm}$ size range, but since the total particle concentration measured by the NAIS was not reliable below about $5 \mathrm{~nm}$, this term was neglected here. As a result, the calculated ion formation rates should be considered as upper limit estimates.

\subsection{Theoretical calculations}

In order to get insight in to molecular mechanisms behind the observed nucleation events, we made quantum mechanics calculations. The calculations were performed using a systematic multi-step method developed recently by our group. Since the method has been described elsewhere (Ortega et al., 2008), only the relevant details are given here.

The applied multi-step method allows us to investigate clusters containing a big organic molecule and up to four sulphuric acid molecules with a reasonable amount of computing time. In this study, the initial geometries of the cluster were chosen using chemical intuition. Then, these structures were pre-optimized at a low level of theory using the SPARTAN program (Wavefunction Inc., 2006). The more stable isomers (usually between 3 and 4 molecules) were optimized using the SIESTA program (Soler et al., 2002). The gradientcorrected BLYP functional (Miehlich et al., 1989) and the double- $\zeta$ polarized (DZP) functions were used. Vibrational harmonic frequencies were also calculated using SIESTA, and they were used to estimate the entropy and thermal contributions to the enthalpy and Gibbs free energy of the clusters.

In order to obtain a reliable energy, the optimized structures obtained from the SIESTA program were used to perform high level single point energy calculations using the TURBOMOLE program (Ahlrichs et al., 1989), with the Resolution of Identity- Moller-plesset second order method (Feyereisen et al., 1993) and the aug-cc-pV(T+d)Z basis set (Dunning et al., 2001). The latter is identical to the aug-cc-
pVTZ basis set for hydrogen, oxygen and nitrogen atoms, and it contains one extra set of $d$-orbitals for the sulfur atoms.

The total aerosol particle number concentrations and sulphuric acid concentration in our experiments were estimated using the MALTE model, a one- or zero-dimensional model which includes several modules for the simulation of chemical and aerosol dynamical processes. A detailed description of the model MALTE can be found in Boy et al. (2006, 2008). All the chemical reaction equations for the model runs were selected from the Master Chemical Mechanism (http://mcm.leeds.ac.uk/MCM/). The Kinetic Pre-Processor (KPP; Sandu and Sanders, 2006) was used to translate the reaction equations into a Fortran 90 code that performs the time integration of the kinetic system. Of the several numerical solvers for systems of differential equations available in KPP, we used the LSODE solver (Radhakrishnan and Hindmarsh, 1993; Sandu et al., 1997). The KPP-produced FORTRAN code was then called from the main MALTE code. Some minimal changes to the KPP-produced code were made. For the $\mathrm{OH}$ yield resulting from the ozonolysis of monoterpenes, we used the values of $0.77,0.70$ and 0.86 in case of $\alpha$ pinene, limonene and $\Delta^{3}$-carene, respectively, following the work by Aschman et al. (2002). A comparison with the full MCM chemical mechanism for $\alpha$-pinene gave a nearly perfect agreement for the simulated hydroxyl radical concentrations. In all other model runs, only the first-order reaction products of monoterpenes were used, since the full reaction schemes for limonene and $\Delta^{3}$-carene are not available on the MCM-website. Potential influences caused by this approximation on aerosol dynamics were compensated by varying the values of two semi-empirical parameters in model simulations, as described below.

Aerosol dynamics inside the MALTE model was simulated with the size-segregated aerosol model UHMA (Korhonen et al., 2004). The formation rate of new aerosol particles by nucleation was calculated by an activation-type nucleation mechanism (Kulmala et al., 2006). In this approach, nucleation is assumed to occur due to the activation of small molecular clusters containing one sulfuric acid molecule, which makes the nucleation rate, $J$, directly proportional to the sulfuric acid concentration, $\left[\mathrm{H}_{2} \mathrm{SO}_{4}\right]$ :

$J=A\left[\mathrm{H}_{2} \mathrm{SO}_{4}\right]$.

Here, $A$ is the so-called nucleation coefficient that carries information on both physics and chemistry of the nucleation process and therefore varies with environmental conditions (e.g. Paasonen et al., 2010). In this study, the value of $A$ was varied for each organic compound over the range of $10^{-5}$ to $10^{-6} \mathrm{~s}^{-1}$.

There is currently a considerable lack of knowledge on the atmospheric oxidation of complex organic molecules such as monoterpenes. This concerns the identities, yields and physico-chemical properties of the first and higher-order reaction products, all of which accumulates into large uncertainties in modelling the secondary organic aerosol formation 
Table 1. Initial conditions for the Set 1 experiments

\begin{tabular}{lccc}
\hline & $\alpha$-pinene & $\Delta^{3}$-carene & Limonene \\
\hline Background particles (DMPS) $\left(\mathrm{cm}^{-3}\right)$ & 66 & 104 & 38 \\
Temperature $\left({ }^{\circ} \mathrm{C}\right)$ & 28.0 & 28.2 & 28.0 \\
Relative humidity $(\%)$ & 29.4 & 26.5 & 21.9 \\
Ozone concentration $(\mathrm{ppb})$ & 6.0 & 6.0 & 8.0 \\
$\mathrm{SO}_{2}$ concentration $(\mathrm{ppb})$ & 0.65 & 0.75 & 0.60 \\
$\mathrm{NO}$ concentration $(\mathrm{ppb})$ & 2.2 & 16.9 & 1.0 \\
$\mathrm{NO}_{2}$ concentration $(\mathrm{ppb})$ & 9.8 & 18.9 & 10.6 \\
Initial monoterpene concentration $\left(10^{12} \mathrm{~cm}^{-3}\right)$ & 2.26 & 1.17 & 1.14 \\
\hline
\end{tabular}

in the atmosphere (Kroll and Seinfeld, 2008; Donahue et al., 2012). Due to these complexities, we took a relatively simple approach to simulate the condensation growth caused by the organic compounds resulting from monoterpene oxidation in our MALTE simulations. We first determined the first-generation oxidation products of monoterpenes at each model time step, then selected condensable vapours from these products, and finally multiplied the amount of these vapours by a factor of 1-10 to take into account higher-order oxidation products contributing to the condensation growth.

Measured concentrations of the organic molecules, $\mathrm{SO}_{2}$, $\mathrm{NO}, \mathrm{NO}_{2}, \mathrm{O}_{3}$, temperature and humidity were read in continuously during the MALTE simulations. No attempt was made to take into account wall losses of particles and trace gases inside the chamber. While causing some bias in simulated total particle number concentrations, this approximation should not influence the main conclusions drawn from our results in this paper.

\section{Results and discussion}

\subsection{Overview of the chamber experiments}

The experiments were performed under dark conditions. In general, we varied three variables to cover different conditions: the initial ozone concentration in the chamber, the amount of a monoterpene introduced into the chamber, and the time the monoterpene was in the chamber. Two different types of experiments were made with regard of the ozone level. In the first of these, we introduced the monoterpene into the chamber when the ozone concentration was low and then increased it. The purpose of these experiments was to find out the ozone level that triggers a nucleation event (Set 1 experiments). In the second type of experiments, we introduced the monoterpene into the chamber only after the ozone concentration was already high (Set 2 experiments). The ozone concentration was varied between these experiments, but it was always greater than what was needed to trigger nucleation based on Set 1 experiments.

The monoterpenes were introduced into the chamber using the procedures described in Sect. 2.1. With the direct
Table 2. Conditions at the start of events in the Set 1 experiments The values below the detection limit are denoted by b.d.

\begin{tabular}{lccc}
\hline & $\alpha$-pinene & $\Delta^{3}$-carene & Limonene \\
\hline Temperature $\left({ }^{\circ} \mathrm{C}\right)$ & 28.4 & 28.7 & 28.3 \\
Relative humidity $(\%)$ & 27.0 & 23.7 & 20.9 \\
Ozone concentration $(\mathrm{ppb})$ & 15.0 & 19.0 & 10.0 \\
$\mathrm{SO}_{2}$ concentration $(\mathrm{ppb})$ & 0.65 & 0.70 & 0.60 \\
$\mathrm{NO}$ concentration $(\mathrm{ppb})$ & b.d. & b.d. & b.d. \\
$\mathrm{NO}_{2}$ concentration $(\mathrm{ppb})$ & 10.9 & 18.9 & 11.7 \\
\hline
\end{tabular}

method we obtained a high monoterpene concentration in the chamber, whereas with the injection method the corresponding concentration was substantially lower compared the direct method. Independently of the method, the permanence of the monoterpene source in the chamber was also controlled. In some experiments the source was kept in the chamber for longer time periods, while in other experiments the source was removed when the event stopped, i.e. when the formation of small particles ended.

The most interesting experiments turned out to be the ones having an initially low ozone concentration that then increased with time (Set 1, see Tables 1 and 2). In these experiments, monoterpenes were introduced into the chamber using the direct method when the ozone concentration was about $6-8 \mathrm{ppb}$. Figure 1 shows the time evolution of the concentrations of the total particle number, ozone and monoterpenes during the experiments. Formation of new particles started earlier for monoterpenes having higher reaction rates with ozone (for the reaction rates, see Calogirou et al., 1998), the minimum ozone level for nucleation to take place being $10 \mathrm{ppb}$ for limonene, $15 \mathrm{ppb}$ for $\alpha$-pinene and $19 \mathrm{ppb}$ for $\Delta^{3}$-carene. Figures 2, 3 and 4 show the number size distributions of particles and ions in the experiments. The duration and shape of the nucleation events produced by different monoterpenes were quite different, as were also the particle formation and growth rates and maximum total number concentrations newly-formed particles (Table 3). Of the three experiments, that with limonene $\left(\Delta^{3}\right.$-carene) had the highest (lowest) formation rate of 2-nm particles, the highest (lowest) total particle number concentration resulting 

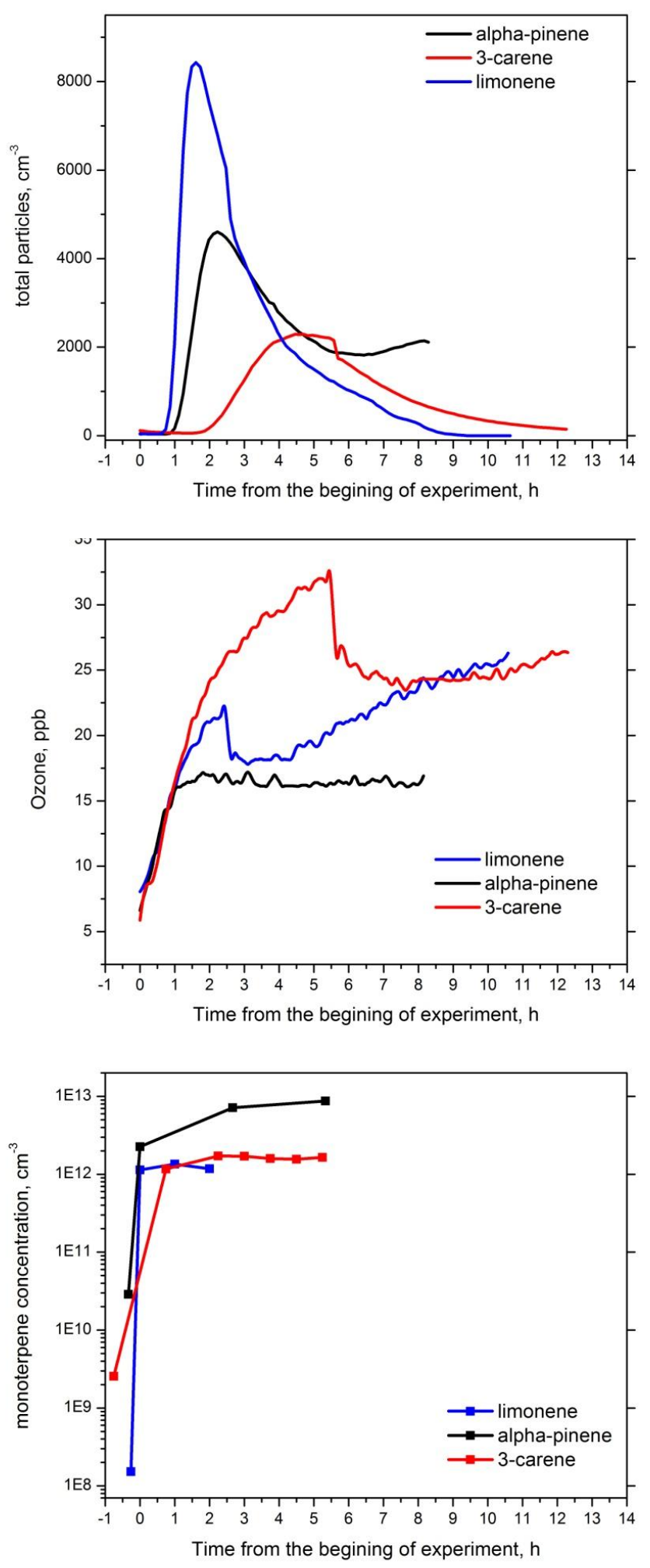

Fig. 1. Time evolution of the total particle number concentrations (top panel), ozone concentrations (middle panel) and monoterpene concentrations (bottom panel) during the selected experiments for limonene (blue line), $\Delta^{3}$-carene (red line) and $\alpha$-pinene (black line). from nucleation, and the shortest (longest) time difference between the introduction of a monoterpene into the chamber and the beginning of the nucleation event. The limonene experiment showed a relatively high particle growth rate (GR) in all the size classes from $<3$ to $25 \mathrm{~nm}$, whereas in the $\alpha$ pinene experiment the GR increased strongly with the increasing particle diameter. The $\Delta^{3}$-carene experiment had the lowest overall GR of the three experiments. In the case of a $\alpha$-pinene (Fig. 2), we kept the organic source in the chamber, which produced a continuous event after the strong initial event, and this latter event lasted as long as the $\alpha$-pinene source was in the chamber.

Daytime atmospheric nucleation tends to be driven by photochemistry and resulting sulfuric acid production (Kerminen et al., 2010; Sipilä et al., 2010). The Set 1 experiments discussed above confirm the important role of ozone and associated monoterpene oxidation in night-time nucleation taking place under dark conditions. Unfortunately, our experiments tell little about the actual nucleation mechanism or identify of the nucleating compounds. It is quite possible that nucleation in the chamber was affected not only by the organic compounds produced from monoterpene oxidation, but also by sulphuric acid produced by the reaction of sulphur dioxide with the $\mathrm{OH}$ radical produced inside the chamber (see Sect. 3.5). Furthermore, reaction of ozone with nitrogen dioxide is expected to produce nitrate radicals, the reaction of which with monoterpenes might also contributed to nucleation and particle growth. The dominance of negative ions over positive ones in the observed events is an indication of the important role of acids (that will be charged negatively) in the nucleation process. This issue will be investigated further in Sect. 3.4.

In addition to Set 1 experiments, we performed several experiments using a high initial ozone concentration (Set 2 experiments). Figure 5 presents particle number size distributions measured by the NAIS for different high level ozone events, in which the monoterpene was introduced into the chamber using the direct method. In general, the total number of particles obtained in this way was much larger than in Set 1 experiments. For example, the maximum particle number concentration produced in limonene set 1 experiment was around $8500 \mathrm{~cm}^{-3}$ (Fig. 1), while in limonene event presented in Figure 5 (middle panel) the maximum was around $35000 \mathrm{~cm}^{-3}$. Figure 6 presents a continuous event produced by limonene introduced by the injection method. In this experiment the limonene flow was kept on and the event continued until we switched off the flow. Due to the slow injection of limone into the chamber, the total particle number concentration was relatively low in spite of the high initial ozone concentration. 

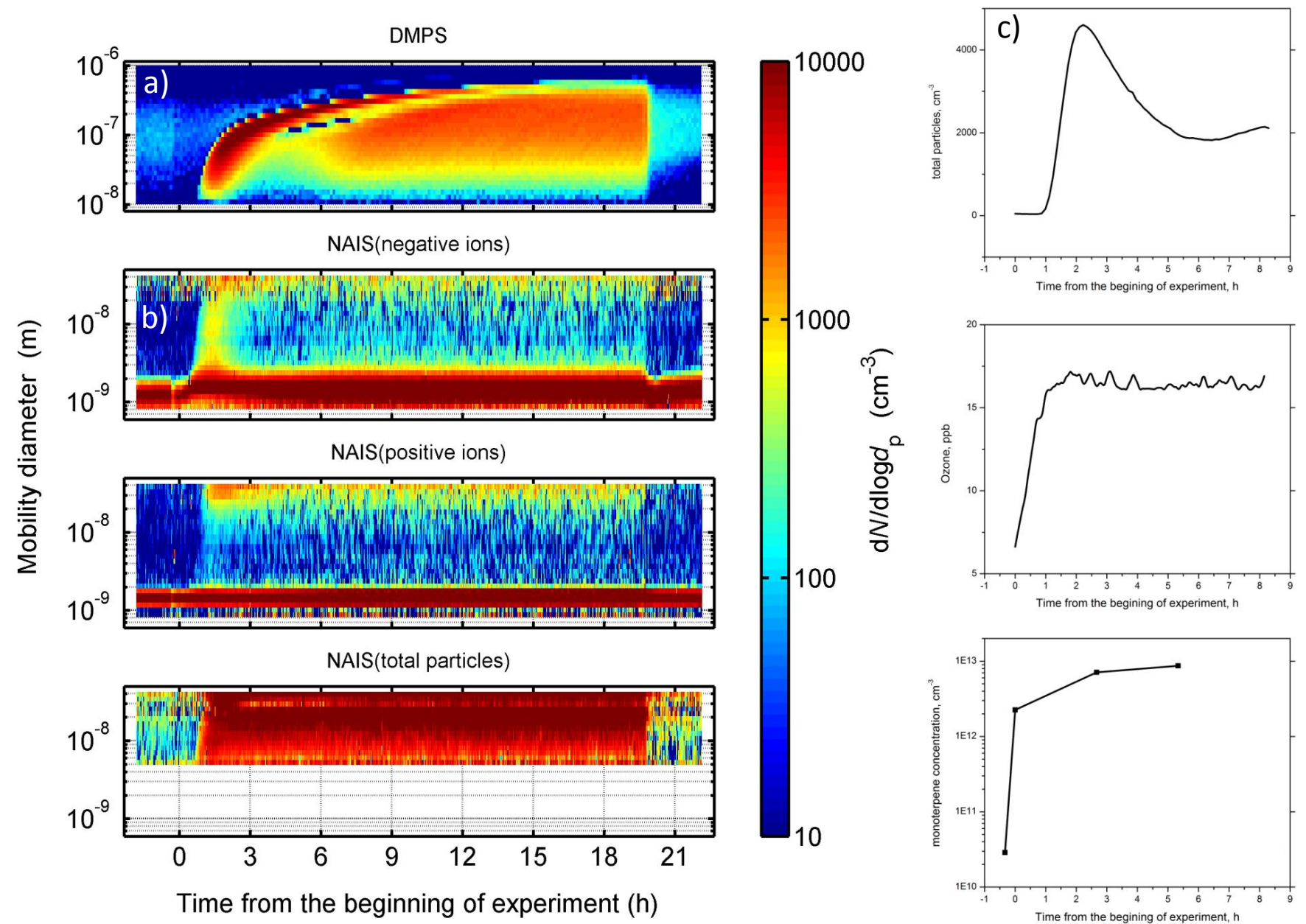

Fig. 2. $\alpha$-pinene event measured on 10-11 November 2008. (a) a DMPS plot showing all particles (neutrals + charged) from 10 to $1000 \mathrm{~nm}$. (b) a NAIS plot showing particles from 0.8 to $40 \mathrm{~nm}$. Top: negative particles; middle: positive particles; bottom: neutral + charged particles. (c) Top: total number of particles per $\mathrm{cm}^{3}$, middle: Ozone concentration in ppb, bottom: $\alpha$-pinene concentration per $\mathrm{cm}^{3}$.

Table 3. Event characteristics and growth rates (GR) for negative ions and all particles (GR-DMPS), ozone at start of event and formation rates for negative 2-nm particles $\left(J_{2}\right)$ for all set one experiments

\begin{tabular}{lccc}
\hline & $\alpha$-pinene & $\Delta^{3}$-carene & Limonene \\
\hline Time from start of experiment (min) & 43 & 80 & 30 \\
Event duration (min) & 73 & 262 & 60 \\
Maximum particle concentration $\left(\mathrm{cm}^{-3}\right)$ & 4600 & 2300 & 8400 \\
GR $<3 \mathrm{~nm}\left(\mathrm{~nm} \mathrm{~h}^{-1}\right)$ & 8.9 & 16.6 & 20.8 \\
GR 3-7 nm $\left(\mathrm{nm} \mathrm{h}^{-1}\right)$ & 21.2 & 22.4 & 58.3 \\
GR 7-20 nm $\left(\mathrm{nm} \mathrm{h}^{-1}\right)$ & 88.9 & 13.5 & 72.4 \\
GR-DMPS 10-25 nm $\left(\mathrm{nm} \mathrm{h}^{-1}\right)$ & 107 & 21.9 & 82.5 \\
Ozone limit $(\mathrm{ppb})$ & 15 & 19 & 10 \\
$J_{2}\left(\mathrm{~cm}^{-3} \mathrm{~s}^{-1}\right)$ & 1.4 & 1.2 & 1.9 \\
\hline
\end{tabular}



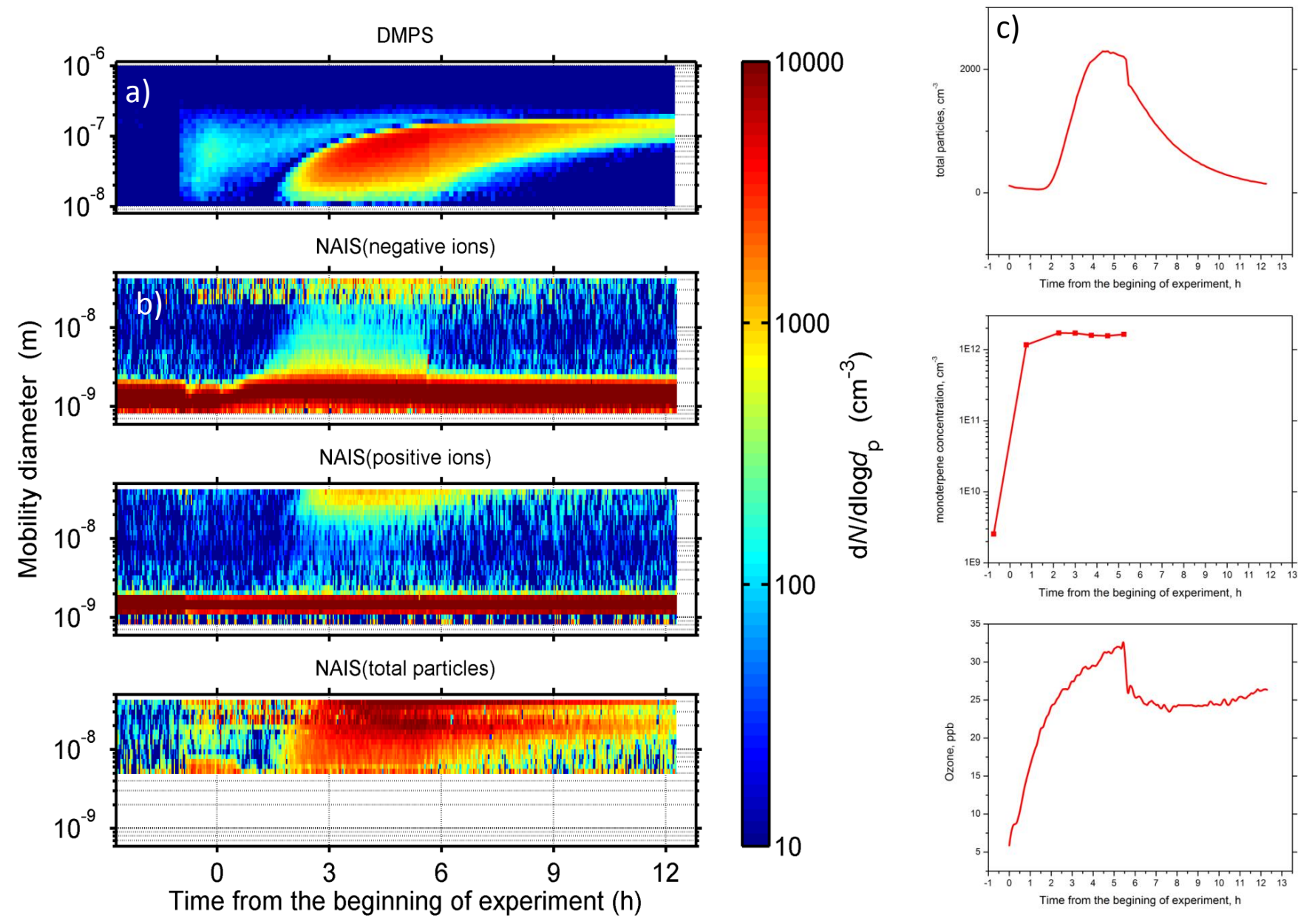

Fig. 3. $\Delta^{3}$-carene event on 12 November 2008. (a) a DMPS plot showing all particles (neutrals + charged) from 10 to $1000 \mathrm{~nm}$. (b) a NAIS plot showing particles from 0.8 to $40 \mathrm{~nm}$. Top: negative particles; middle: positive particles; bottom: neutral + charged particles. (c) Top: total number of particles per $\mathrm{cm}^{3}$, middle: Ozone concentration in $\mathrm{ppb}$, bottom: $\Delta^{3}$-carene concentration per $\mathrm{cm}^{3}$.

\subsection{Event types}

Five main types of events were observable during 2005-2007 in Tumbarumba (Fig. 7, see Suni et al. (2008) for the description of the measurement campaign). These include narrow, pointed spikes starting in the cluster mode and typically not reaching the Aitken mode (Fig 7a), rounder, low bumps not growing much from the cluster mode (Fig 7b), nocturnal $b a$ nanas, more upright than daytime bananas (Fig. 7c), series of narrow, upright sticks extending from the cluster mode all the way up to the Aitken mode - the most common nocturnal event type (Fig 7d), and massive, often hours long continuous curtains extending from the cluster mode to the Aitken mode and covering the whole size range in between (Fig. 7e). Some of the different nocturnal event types observed in the field could, indeed, seen in the chamber experiments. The shapes of the events seen in our experiments were dependent on (i) the initial concentrations of ozone and monoterpenes, and (ii) whether the monoterpene source was continuous or not. We divided the events broadly into self-ending events and continuous events.

\subsubsection{Self-ending events - bananas and sticks}

Nucleation events obviously end when they run out of source material, as took place on 29 October when a banana event occurred at an ozone level of $10 \mathrm{ppb}$ and an initial limonene concentration of $\sim 8 \times 10^{11} \mathrm{~cm}^{-3}$ but with no further source (Fig. 5, top panel). Another clear example of this kind of behavior is the $\Delta^{3}$-carene experiment on 12 November (Fig. 3), in which the $\Delta^{3}$-carene source was removed from the chamber after the event stabilized.

An event can also end by itself in the presence of a source, provided that the burst of particles is large enough so that a resulting large condensation sink effectively inhibits further nucleation. This was usual in the experiments where a monoterpene was introduced into the chamber using the direct method and the initial ozone concentration was high. 

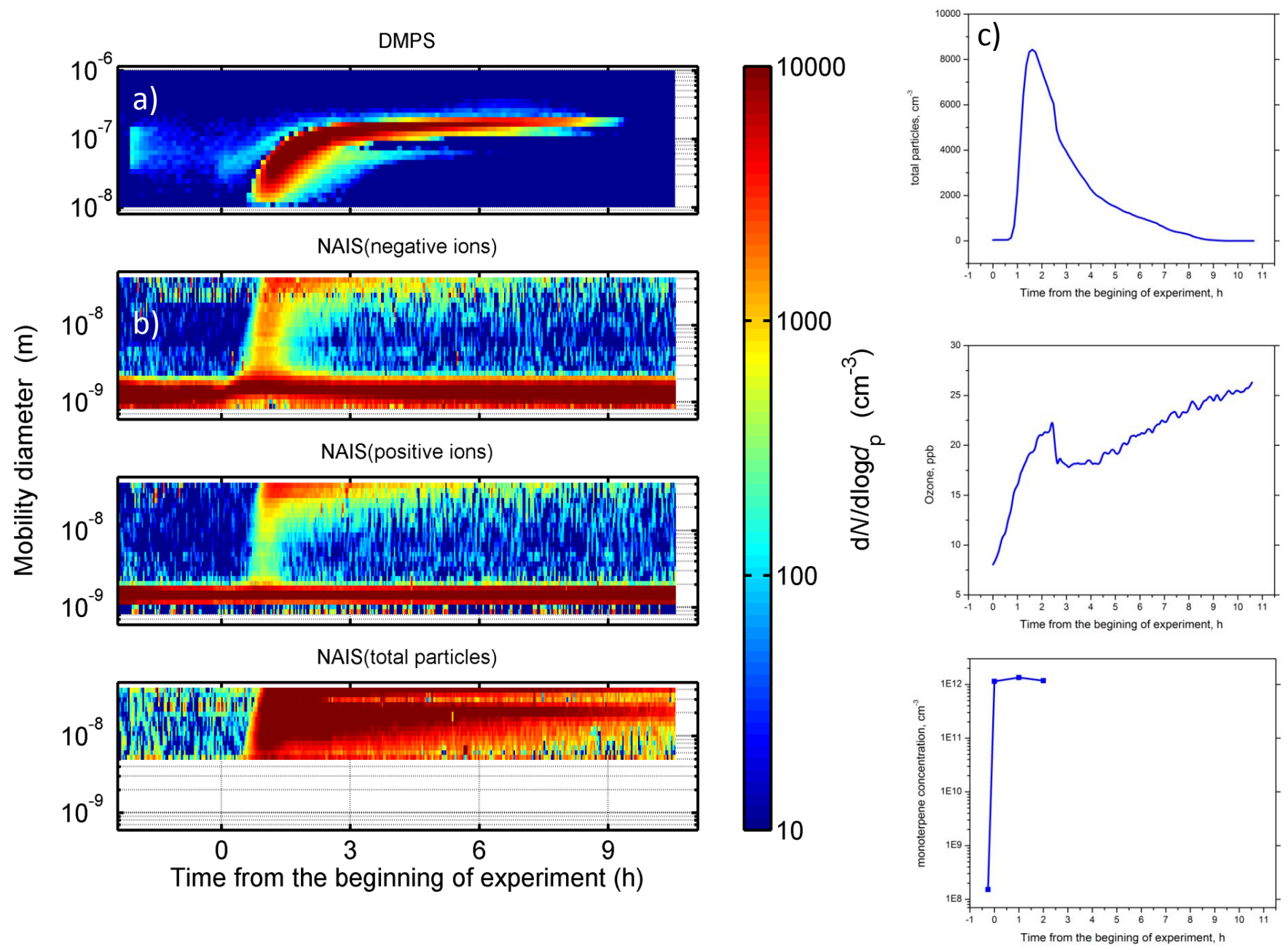

Fig. 4. Limonene event on 14 November 2008. (a) a DMPS plot showing all particles (neutrals + charged) from 10 to $1000 \mathrm{~nm}$. (b) a NAIS plot showing particles from 0.8 to $40 \mathrm{~nm}$. Top: negative particles; middle: positive particles; bottom: neutral + charged particles. c) Top: total number of particles per $\mathrm{cm}^{3}$, middle: Ozone concentration in $\mathrm{ppb}$, bottom: limonene concentration per $\mathrm{cm}^{3}$.

An example of such behavior was the limonene experiment on 31 October, in which the particle number concentrations reached $12000 \mathrm{~cm}^{-3}$ in just $10 \mathrm{~min}$ (Fig. 5, middle panel). In the limonene experiment on 14 November (Fig. 4), the nucleation event also ended in just $60 \mathrm{~min}$ after producing a maximum concentration of $8400 \mathrm{~cm}^{-3} \cdot \Delta^{3}$-carene produced a roughly banana-shaped event on 6 November at the ozone level of 14-16 ppb. The event lasted about one hour and ended when the total particle number concentration reached about $6600 \mathrm{~cm}^{-3}$ (Fig. 5, bottom panel) although the source was still inside the chamber. $\alpha$-pinene produced a very similar event lasting one hour on 6 November at the initial ozone concentration of $20 \mathrm{ppb}$ (Fig. 5, bottom panel). The maximum total particle concentration reached about $7300 \mathrm{~cm}^{-3}$, after which the event ended.

The main difference between the banana and stick events is the extremely fast particle growth in the latter ones. Stick events were observed when we introduced a high concentra- tion of limonene into the chamber with a high initial ozone concentration, producing a fast burst of particles which acted as a condensation sink and ended the event. The limonene experiment on 31 October is a clear example of the stick events (Fig. 5, middle panel). $\Delta^{3}$-carene and $\alpha$-pinene produced only banana events, even when using high initial ozone concentrations and direct method for the injection monoterpenes. The reason for this kind of behavior is the higher oxidation rate of limonene compared with $\alpha$-pinene and $\Delta^{3}$ carene, generating larger amounts of low-volatile organic compounds and thereby higher total particle number concentrations over shorter time scales.

Hump and spike events are kind of "short" banana and stick events, respectively, in which the particle growth to larger sizes is severely limited. Under field conditions, banana and stick events are indicative of regional new particle formation taking place over spatial scales of at least tens of kilometers (e.g. Kulmala and Kerminen, 2008), whereas 


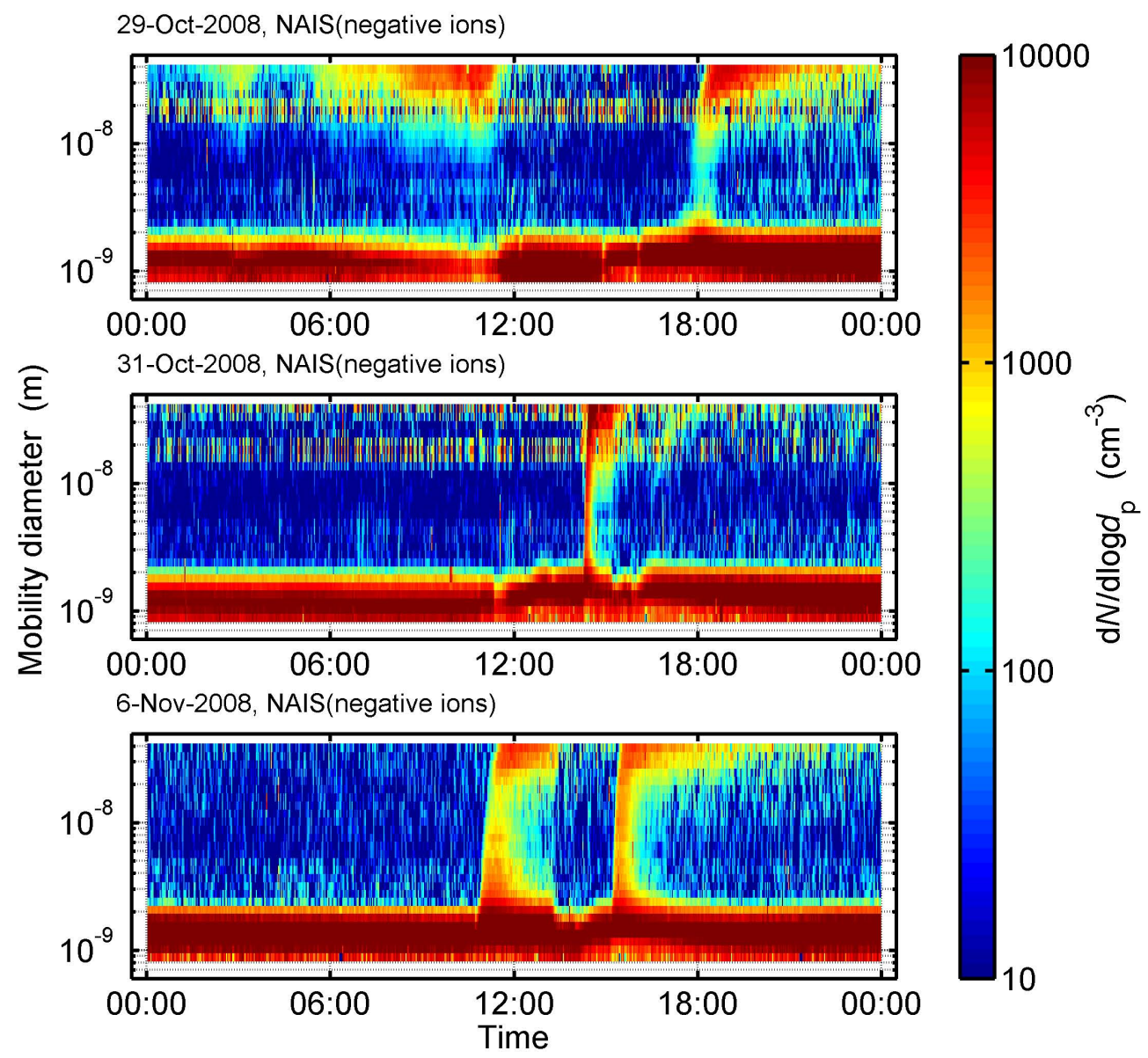

Fig. 5. Self-ending banana/stick events. Top: limonene event on 29 October 2008, produced in an empty chamber with initial ozone concentration of $10 \mathrm{ppb}$. Middle: Limonene event on 31 October 2008, with initial ozone concentration of $16 \mathrm{ppb}$. Bottom: $\Delta 3$-carene and $\alpha$-pinene events on 6 November 2008, produced at 14 and $20 \mathrm{ppb}$ of ozone, respectively.

hump and spike events might result from new particle formation confined to much smaller spatial scales (e.g. Ehn et al., 2010). The fact that we did not see any hump or spike events in our laboratory experiments supports this interpretation, since none of our experiments had boundary conditions that imitate continuous yet spatially limited new particle formation.

An interesting feature in some of the experiments was that nucleation was observed in neutral particles size distributions only. In these experiments charged particles appeared eventually into the Aitken-mode, like in the $\Delta^{3}$-carene experiment in Fig. 3. Possible reasons for the absence of charged nucleation-mode particles was that the nucleation took place mostly via a neutral pathway, and the nucleated particles grew so rapidly that they did not get detectable amount of charge until reaching larger sizes (e.g. Kerminen et al., 2007; Leppä et al., 2009). This is very important from the point of view of field event classification: if based on sole ion size distribution measurements, events classified as Aitken events could, in fact, be typical bananas for neutral particles.

\subsubsection{Continuous events - curtains}

We observed three overnight curtain events when a continuous source of monoterpene (either direct or injection method used) was kept in the chamber and the initial ozone concentration was low. In this way, the total number of particles produced was low enough to avoid the end of the event due to the increase of the condensation sink. One such event was produced with $\alpha$-pinene on 10-11 November (Fig. 2), and two with slowly-injected limonene, 4-5 November (not shown) and 7-10 November (Fig. 6). In case of the $\alpha$-pinene experiment and the second limonene experiment, the total particle number concentration became stable at about $2000 \mathrm{~cm}^{-3}$. In the first limonene experiment the total particle number concentration stabilized at about $1200 \mathrm{~cm}^{-3}$.

Curtain events, the most surprising event type in the field, were always produced if two conditions were met: 1) slow enough nucleation rate that did not lead to too high condensational sink to stop formation of new particles, and (2) a continuous source of monoterpene(s). The first of these conditions could be attained in several ways. Even high 

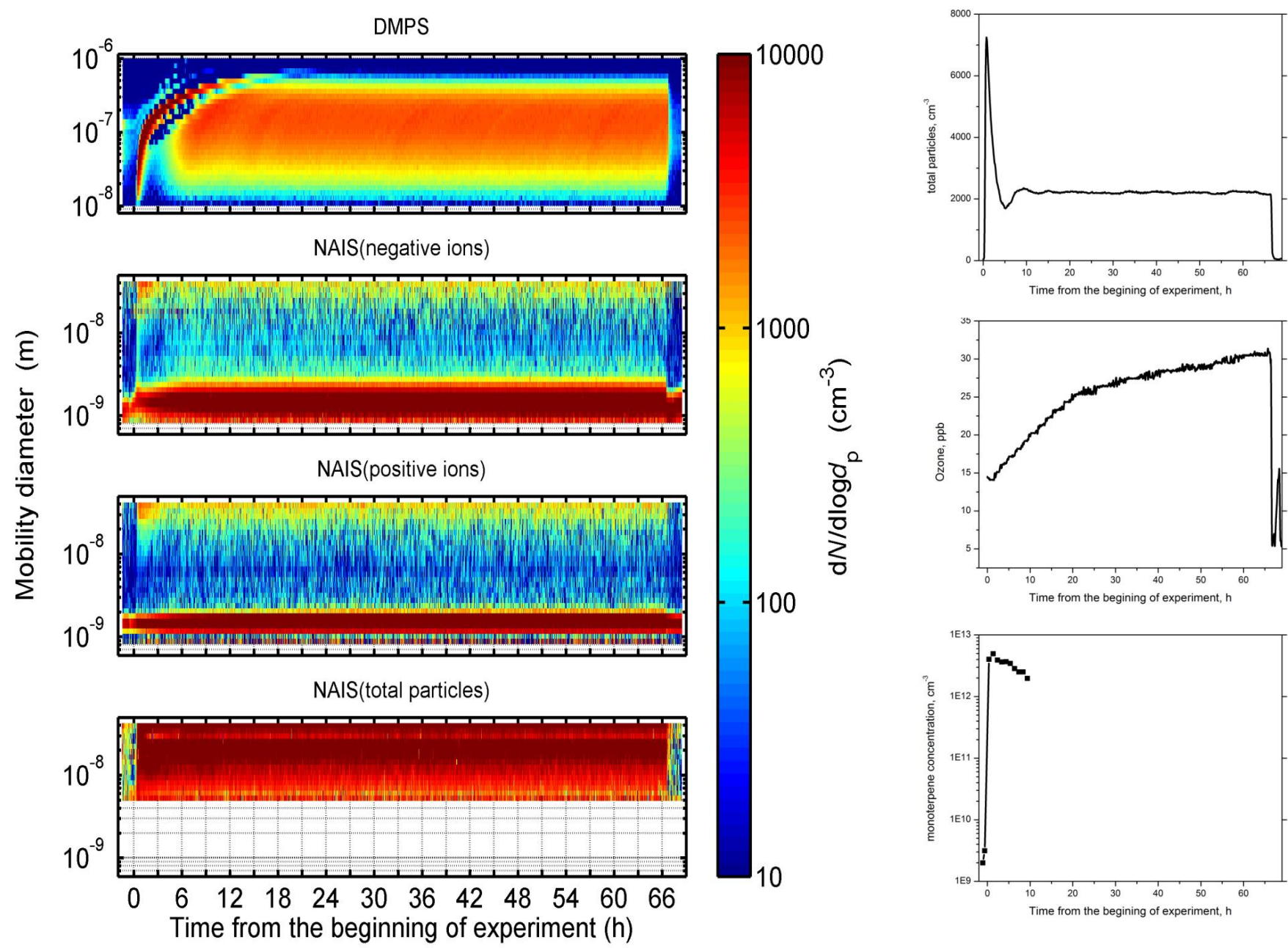

Fig. 6. Limonene curtain event on 7-10 November 2008. (a) DMPS plot showing all particles (neutrals + charged) from 10 to $1000 \mathrm{~nm}$. (b) a NAIS plot showing particles from 0.8 to $40 \mathrm{~nm}$. Top: negative particles; middle: positive particles; bottom: neutral + charged particles. (c) Top: total number of particles per $\mathrm{cm}^{3}$, middle: Ozone concentration in ppb, bottom: limonene concentration per $\mathrm{cm}^{3}$.

concentrations of weakly-reactive monoterpenes, such as $\alpha$ pinene or $\Delta^{3}$-carene, kept the total particle number concentration low when ozone was slowly increased from low levels to trigger nucleation (Figs. 2 and 3). On the other hand, for a highly reactive monoterpene, such as limonene, the only way to keep the event slow was to have a slow injection of $2 \times 10^{12} \mathrm{~cm}^{-3}$ limonene concentration and low ozone concentration of around $10 \mathrm{ppb}$ (Fig. 4). The total particle concentration during these curtain events stabilized at about $1000-2000 \mathrm{~cm}^{-3}$ which is equal to the average background particle concentration in forests such as Tumbarumba and the boreal zone (Suni et al., 2008; Dal Maso et al., 2007).

\subsection{Organic aerosol chemical composition}

We used an AMS to get an idea of the composition of the particles formed during the experiments. Once the particles had grown to $\sim 50 \mathrm{~nm}$, electron impact ionization mass spectra could be acquired. Due to the ionization method, the AMS causes considerable fragmentation of the original molecules in the particles. However, the fragmentation patterns still provide information on the aerosol composition and different types can often be identified. The organic mass spectrum during the $\alpha$-pinene events resembled those previously measured by e.g. Bahreini et al. (2005). The limonene SOA mass spectrum was similar to $\alpha$-pinene, with the dominant ion being $m / z 43\left(\mathrm{C}_{2} \mathrm{H}_{3} \mathrm{O}^{+}\right)$. In the $\Delta^{3}$-carene experiments, the dominant ion was found to be $\mathrm{m} / \mathrm{z} 29\left(\mathrm{CHO}^{+}\right)$.

We did not identify sulphate-related peaks in any of the experiments, which means that the mass of sulphate in the particles was well below $1 \%$ of the total mass of the particles (typically a few $\mu \mathrm{g} / \mathrm{m}^{3}$ or less). This demonstrates that the particles contained mainly organic material. However, considering that the mass of a $1 \mathrm{~nm}$ particle is $10^{6}$ times smaller than the mass of a $100 \mathrm{~nm}$ particle, the AMS data mainly measures compounds accounting for the growth of nucleated 



Fig. 7. Nocturnal event classification based on measurement in Tumbarumba in 2005-2007. (a) spikes: two clear spikes in the early morning hours; (b) a bump at 07:00; (c) a typical nocturnal banana at 22:00, more upright than a daytime banana; (d) a stick series in the early morning hours - the most common nocturnal event type; (e) a curtain in the early morning hours and in the late evening after 21:00. Between the curtains there was rain.

particle, and these compounds are not necessarily the same as those participating in nucleation. The main conclusion from the AMS measurements is that organic compounds were responsible for the particle growth, and the specific organics varied depending on the precursors, as expected. Due to the minimum detectable size of about $50 \mathrm{~nm}$, the AMS could provide no information on which compounds participated in nucleation.

\subsection{Quantum chemical calculations}

Experimental results showed that monoterpene oxidation products were most likely involved in nucleation and growth of the observed particles. In order to get some insight into the molecular mechanism behind the observed formation events, we decided to make quantum mechanical calculations. The large number of compounds produced by ozone oxidation of these monoterpenes makes it impossible to calculate all possible cluster combinations, so we had to choose the best candidates. We focused on some of the major products of ozone oxidation of the selected monoterpenes (Glasius et al., 2000). Although this reduced the number of compounds, it was still out of our computational possibilities, so as a second approximation we focused on acids only. The high formation rate of negative ions in the observed nucleation events is sugges- tive of the involvement of acids in the nucleation process. In addition, the driving force for the formation of clusters is the formation of hydrogen bonds, and carboxylic acid functional groups can form more hydrogen bonds than other functional groups (e.g. carbonyl or alcohol groups). As a result, the choice of organic acids for this study seems reasonable. The compounds chosen were limonic acid, limononic acid, 7-hydroxyl-limononic (OH-pinonic) acid, pinic acid, pinonic acid, 7-hydroxy-pinonic (OH-pinonic) acid, caric acid, caronic acid and 7-hydroxyl-caronic (OH-caronic) acid.

The molecular size of the organic acids makes the quantum mechanics calculations computational demanding, so we first calculated the formation energies of dimers containing one molecule of organic acid and one molecule of sulfuric acid (Table 4). Based on these results, we then selected from each monoterpene the acid which forms the most stable cluster. Finally, we extended the calculations for those compounds to clusters containing up to four sulfuric acid molecules. In order to estimate how the presence of the organic molecule in the cluster affects the cluster growth, we calculated the addition energy of one sulfuric acid molecule to the cluster (Table 5): 
Table 4. Formation free energies $\left(\mathrm{kcal} \mathrm{mol}^{-1}\right)$ calculated for different clusters containing one organic acid molecule and one sulphuric acid molecule.

\begin{tabular}{lc}
\hline Organic acid & Formation free energy \\
\hline Limonic & -4.72 \\
Pinic & -7.39 \\
Caric & -10.76 \\
Limononic & -10.83 \\
Pinonic & -9.65 \\
Caronic & -14.59 \\
OH-limononic & -6.91 \\
OH-pinonic & -11.37 \\
OH-caronic & -19.57 \\
\hline
\end{tabular}

Table 5. Free energy $\left(\mathrm{kcal} \mathrm{mol}^{-1}\right)$ for the addition of one sulphuric acid molecule onto a cluster containing one organic acid molecule and $n$ sulphuric acid molecules.

\begin{tabular}{lrrr}
\hline$N$ & 1 & 2 & 3 \\
\hline SA & -6.90 & -3.17 & -3.88 \\
Limononic & -6.75 & -2.97 & -4.28 \\
OH-pinonic & -15.25 & -1.40 & -6.76 \\
OH-caronic & -1.05 & -2.95 & -10.35 \\
\hline
\end{tabular}

Organic acid $\cdot\left(\mathrm{H}_{2} \mathrm{SO}_{4}\right)_{n}+\mathrm{H}_{2} \mathrm{SO}_{4}$

$\rightarrow$ Organic acid $\cdot\left(\mathrm{H}_{2} \mathrm{SO}_{4}\right)_{n+1}, n=1-3$

By comparing this addition energy with the one for pure sulfuric acid cluster, we could get an estimate of the role of organic acids in the clusters growth.

In Fig. 8 we represent the formation free energy of clusters containing different organic acids versus the number of sulfuric acid molecules in the cluster after the sulfuric acid addition. We can see how the presence of limonene practically does not affect the addition energy of sulfuric acid: the two lines almost overlap in all cluster sizes. In other words, the stability of clusters containing limononic acid will be practically the same as those consisting only pure sulfuric acid. For these clusters, the most unfavorable step is the addition of the third sulfuric acid molecule $\left(-3.17 \mathrm{kcal} \mathrm{mol}^{-1}\right.$ for pure sulfuric acid and $-2.97 \mathrm{kcal} \mathrm{mol}^{-1}$ for limononic acid clusters). In case of $\mathrm{OH}$-pinonic acid, we can see how the addition of sulfuric acid is really favorable for the small clusters, with a local minimum in clusters containing two sulfuric acids. On the other hand, the addition of a third sulfuric acid molecule to this local minimum is quite unfavorable $\left(-1.40 \mathrm{kcal} \mathrm{mol}^{-1}\right)$. For $\mathrm{OH}-$ caronic acid, we have a similar behavior, but this time the most stable cluster is the one formed by one sulfuric acid molecule and one organic acid, so the addition of a second sulfuric acid molecule is quite unfavorable $\left(-2.95 \mathrm{kcal} \mathrm{mol}^{-1}\right)$.
Table 6. Free energy $\left(\mathrm{kcal} \mathrm{mol}^{-1}\right)$ for the addition of the second organic acid molecules onto clusters containing 1-2 sulphuric acid and organic acid molecules.

\begin{tabular}{lr}
\hline Reaction & Free energy \\
\hline $\mathrm{LA} \cdot\left(\mathrm{H}_{2} \mathrm{SO}_{4}\right)_{2}+\mathrm{LA} \rightarrow(\mathrm{LA})_{2} \cdot\left(\mathrm{H}_{2} \mathrm{SO}_{4}\right)_{2}$ & -10.02 \\
$\mathrm{OH}$ inin $\left(\mathrm{H}_{2} \mathrm{SO}_{4}\right)_{2}+\mathrm{OHpin} \rightarrow(\mathrm{OHpin})_{2} \cdot\left(\mathrm{H}_{2} \mathrm{SO}_{4}\right)_{2}$ & -19.00 \\
$\mathrm{OHcar} \cdot \mathrm{H}_{2} \mathrm{SO}_{4}+\mathrm{OHcar} \rightarrow(\mathrm{OHcar})_{2} \cdot \mathrm{H}_{2} \mathrm{SO}_{4}$ & -15.37 \\
$(\mathrm{OHcar})_{2} \cdot \mathrm{H}_{2} \mathrm{SO}_{4}+\mathrm{H}_{2} \mathrm{SO}_{4} \rightarrow(\mathrm{OHcar})_{2} \cdot\left(\mathrm{H}_{2} \mathrm{SO}_{4}\right)_{2}$ & -4.16 \\
\hline
\end{tabular}

Table 7. The values of the nucleation coefficient (A) and the factor for condensation for the simulations with the MALTE model.

\begin{tabular}{lcc}
\hline & $A\left(\mathrm{~s}^{-1}\right)$ & Factor for condensation \\
\hline Limonene & $2.5 \times 10^{-6}$ & 2 \\
$\alpha$-pinene & $2.0 \times 10^{-6}$ & 4 \\
$\Delta^{3}$-carene & $1.5 \times 10^{-6}$ & 3 \\
\hline
\end{tabular}

These findings motivated a third stage in our calculations, the addition of a second molecule of organic acid to the clusters. We studied the addition of this second organic acid molecule to the most stable cluster for each monoterpene. These were two sulfuric acid and limononic acid clusters, two sulfuric acid and $\mathrm{OH}$-pinonic acid clusters, and sulfuric acid and $\mathrm{OH}$-caronic acids clusters. In order to evaluate the further growth of $\mathrm{OH}$-caronic acid clusters, we also calculated the addition energy of a second sulfuric acid molecule to clusters containing $2 \mathrm{OH}$-caronic acids. The results are summarized in Table 6.The addition of a second limononic acid molecule to limononic acid and two sulfuric acid clusters is more favorable than the addition of a third sulfuric acid molecule by $8 \mathrm{kcal} \mathrm{mol}^{-1}$. These clusters will prefer to grow by adding limononic acid rather than by adding sulfuric acid. For OH-pinonic acid clusters the situation is similar: the addition of a second organic acid molecule is more favorable by $17 \mathrm{kcal} \mathrm{mol}^{-1}$, so again these cluster will prefer grow by the addition of an organic acid molecule. The situation with $\mathrm{OH}-$ caronic acid is also pretty similar: the addition of a second organic acid molecule is $14 \mathrm{kcal} \mathrm{mol}^{-1}$ more favorable, but in this case, the resulting cluster has just one sulfuric acid molecule. We then calculated the addition energy of a second sulfuric acid molecule to this cluster. By this way, we reached the same composition as for the other clusters (two organic acids and two sulfuric acids). As can be seen from Table 6, the presence of a second organic acid molecule in the cluster does not make the addition energy of a second sulfuric acid molecule more favorable (difference of about $1 \mathrm{kcal} \mathrm{mol}^{-1}$ ), so even with a second organic acid molecule present in the cluster, the further growth is still less favorable for $\mathrm{OH}$-caronic acid as compared with the other organic acids studied. 


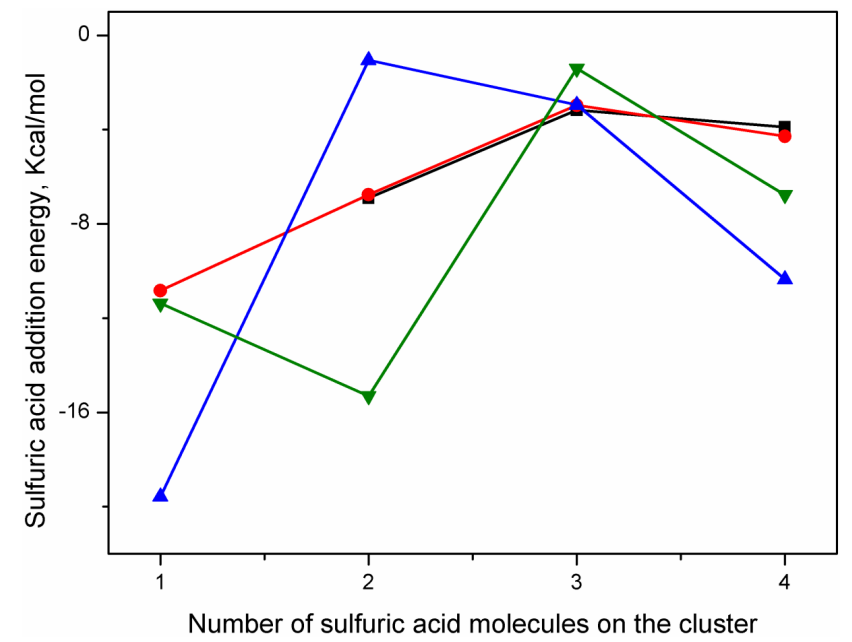

Fig. 8. Addition energy of sulphuric acid versus number of sulphuric acid molecules in the cluster. Black line: pure sulphuric acid clusters, Red line: clusters containing one molecule of limononic acid, Blue line: clusters containing one molecule of $\mathrm{OH}$-caronic acid, Green line: clusters containing one molecule of $\mathrm{OH}$-pinonic acid.

The quantum mechanics calculations are, generally speaking, in a good agreement with observations. It is clear that the presence of $\mathrm{OH}$-caronic acid in the cluster is the one that least favors the growth of clusters. However, according to our results, the addition of a second molecule of $\mathrm{OH}$-pinonic acid to the clusters is around $5 \mathrm{kcal} \mathrm{mol}^{-1}$ more favorable than the addition of a second limononic acid molecule. The experiments showed that limonene produced particles much more efficiently than $\alpha$-pinene. There are different explanations for these small discrepancies. For example, the number of oxidation products for limonene is quite high, and we needed to make a selection of those products, so maybe the oxidation product responsible for the nucleation events observed in the experiments is none of the ones chosen for the present calculations. This will leave the question of which specific molecule is behind of this events open, and will require a deeper study focusing only on limonene. On the other hand, the high oxidation rate of limonene will lead to a rapid formation of large amounts of low volatility vapors that can condense on the clusters. The strong events observed with limonene may not be produced only by the participation of a certainty compound which enhances the growth of clusters to the critical size, but also by the fast condensation of these low volatility vapors onto formed clusters.

\subsection{Simulations with the MALTE Model}

Model simulations were made by varying the values of two semi-empirical parameters: the nucleation coefficient $(A)$ and the value of the factor aiming to take into account higherorder monoterpene oxidation products contributing to the condensation growth of clusters up to the Aitken mode (see
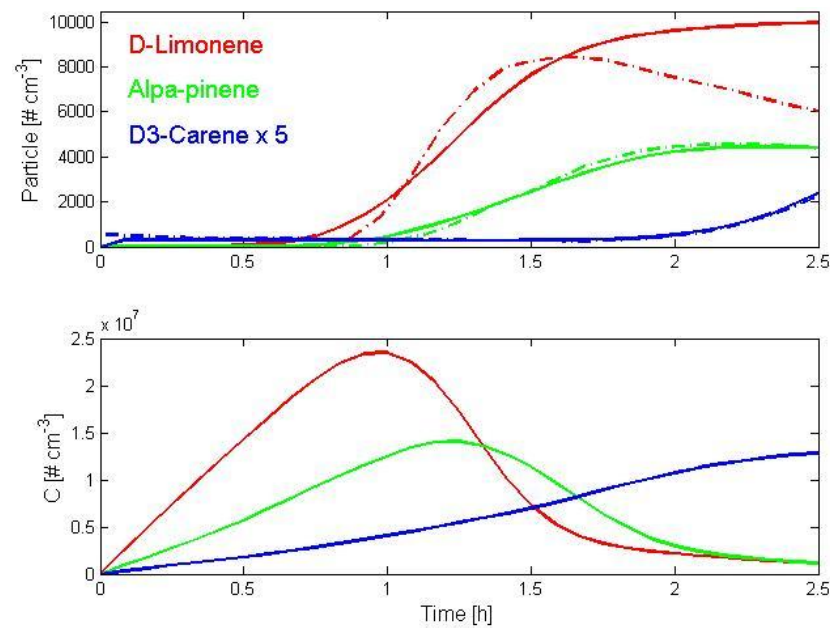

Fig. 9. Upper plot: modelled (solid lines) and measured (dashed lines) total particle number concentrations for particles with a diameter $>20 \mathrm{~nm}$ for in the Set 1 experiments. Lower plot: modelled sulphuric acid concentrations in the same Set 1 experiments.

Sect. 2.3). Table 7 gives the values of semi-empirical parameters that gave the best agreement between the measured and modeled time evolution of the total number concentrations of particles $>20 \mathrm{~nm}$ in the Set 1 experiments. The corresponding curves for the total particle number concentration along with calculated sulphuric acid concentrations are depicted in Fig. 9.

Based on recent findings from field measurements, laboratory experiments and model simulations (Metzger et al., 2010; Paasonen et al., 2010; Lauros et al., 2011), we assumed that both sulphuric acid and organic compound participate into the formation of small clusters. With this assumption, we would expect that the values of nucleation coefficients for the three different monoterpenes were related to the enhancement of nucleation caused by their reaction products. Our results, after varying both semi-empirical parameters simultaneously, predict that the contribution of limonene to the cluster formation process was $20 \%$ and $40 \%$ higher than the contributions of $\alpha$-pinene and $\Delta^{3}$-carene, respectively. This is in good agreement with the measurements which showed an increase in the formation rate of 2-nm particles of $26 \%$ and $39 \%$ when comparing the limonene experiment with the $\alpha$-pinene and $\Delta^{3}$-carene experiments, respectively (see Table 3). We should note, however, that the difference of 20 and $40 \%$ for the predicted value of the coefficient lies inside the uncertainties of the model setup and simulations. With these considerations we can state that the model results support our theoretical conclusions but, on the other hand, these results cannot be taken as a proof for our hypothesis. 


\section{Conclusions}

Our dark chamber experiments showed that in the presence of ozone, several monoterpenes are able to produce newparticle formation events in a similar way as has been observed under field conditions. However, the role of different monoterpenes in this process seemed to vary. In our experiments, $\Delta^{3}$-carene appeared to be preferably involved in nucleation, $\alpha$-pinene in subsequent particle growth, and limonene in both. This indicates that each monoterpene should be included in the models individually, and not as a whole. The ozone concentrations needed for initiating a nucleation event under dark conditions were comparable to those in the ambient atmosphere. This suggests that the compounds studied could be associated with the nocturnal nucleation events observed in the ambient atmosphere.

We were able to reproduce most of the different shapes of nucleation events observed in Tumbarumba, Australia. The shape of the observed events depended not only on the used monoterpene, but also on the initial ozone and monoterpene concentration as well as the duration of the monoterpene emission. We were able to reproduce stick events only using a high concentration of limonene and ozone in the chamber, but we could not reproduce them by using $\Delta^{3}$-carene or $\alpha$-pinene, even when using high concentrations of these monoterpenes and ozone. Banana event could be obtained with all the three monoterpenes. Curtains events could be reproduced with $\alpha$-pinene and limonene, but only when the monoterpene source was in the chamber and the monoterpene was injected slowly at low concentrations. In this way, we did not form too many particles to suppress nucleation due to an increased condensation sink inside the chamber.

By using the AMS measurements, we confirmed the dominant role of organics in the particle growth. On the other hand, the sizes of particles detectable by AMS were too large to get qualitative information about nucleating compounds. Our model simulations showed that the contribution of limonene in the cluster formation process is likely to be higher than the contributions of $\alpha$-pinene and $\Delta^{3}$-carene, which was in good agreement with the intensity of the observed nucleation events in the chamber. Quantum mechanical calculations showed that it is energetically favourable for limononic and $\mathrm{OH}$-pinonic acids to add a second molecule of organic acid to clusters containing two sulphuric acid molecules and one organic acid molecules, rather than to add a third sulphuric acid molecule. Unfortunately, the limonene oxidation products responsible for the nucleation events are still unknown, so a deeper computational study focusing exclusively on this monoterpene will be necessary to shed new light on this issue.

By combining experiments, aerosol dynamics modelling and quantum mechanical calculations, we have been able to improve our knowledge about nocturnal new particle formation events. The three different approaches led to the same conclusion: the oxidation products of monoterpenes are be- hind the observed events. There seems to be a number of factors that dictate the strength, duration and shape of the observed events. By using quantum mechanical calculations, we found that clusters of a certain size will prefer to add an organic acid molecule instead of a sulphuric acid molecule. Although many questions were answered in this study, there is still several questions that needs to be answered, including: which specific limonene oxidation products are participating in the strong nocturnal nucleation events?, how does the system behave over broader ranges of temperature and humidity?, what is the exact role of sulphuric acid in the initial stages of nocturnal nucleation and how large amounts of sulphuric acid are needed in this process?, and do nitrate radicals influence the dynamics of this system and under which conditions? In order to answer these questions, we need additional laboratory experiments aided with deeper and computationally more demanding quantum chemical studies that cover, for example, a larger variety of limonene oxidation products.

Acknowledgements. This research was supported by the Academy of Finland Center of Excellence program (project number 1118615 ) and by the project,-FP7-ATMNUCLE project No. 227463 (ERC Advanced Grant). The authors thank the Scientific Computing Center (CSC) in Espoo, Finland for the computing time.

Edited by: A. Wiedensohler

\section{References}

Aalto, P., Hämeri, K., Becker, E., Weber, R., Salm, J., Mäkelä, J. M., Hoell, C., O’Dowd, C.D., Karlsson, H., Hansson, H.-C., Väkevä, M., Koponen, I. K., Buzorius, G. and Kulmala, M.: Physical characterization of aerosol particles during nucleation events, Tellus, 53B, 344-358, 2001.

Ahlrichs, R., Bär, M., Häser, J., Horn, H., and Kölmel C.: Electronic structure calculations on workstation computers: the program system TURBOMOLE, Chem. Phys. Lett., 162, 165-169, 1989.

Aschman, S., Arey, J., and Atkinson, R.: OH radical formation from the gas-phase reactions of $\mathrm{O}_{3}$ with a series of terpenes, Atmos. Environ., 36, 4347-4355, 2002.

Bahreini, R.: Measurements of SOA from oxidation of cycloalkenes, terpenes, and m-xylene using an AMS, Environ. Sci. Technol., 39, 5674-5688, 2005.

Boy, M., Hellmuth, O., Korhonen, H., Nilsson, E. D., ReVelle, D., Turnipseed, A., Arnold, F., and Kulmala, M.: MALTE - model to predict new aerosol formation in the lower troposphere, Atmos. Chem. Phys., 6, 4499-4517, doi:10.5194/acp-6-4499-2006, 2006.

Boy, M., Kazil, J., Lovejoy, E. R., Korhonen, H., Guenther, A., and Kulmala, M.: Relevance of ion-induced nucleation of sulphuric acid and water in the lower troposphere over the boreal forest at northern latitudes, Atmos. Res., 90, 151-158, 2008.

Brown, S. S., Dube, W. P., Peischl, J., Ryerson, T. B., Atlas, E., Wameke, C., de Gouw, J. A., te Lintel Hekkert, S., Brock, C. 
A., Flocke, F., Trainer, M., Parrish, D. M., Feshenfeld, F. C., and Ravishankara, A. R.: Budgets for nocturnal VOC oxidation by nitrate radicals aloft during the 2006 Texas Air Quality Study, J. Geophys. Res., 116, D24305, doi:10.1029/2011JD016544, 2011.

Calogirou, A., Larsen, B. R., and Kotzias, D.: Gas-Phase terpene oxidation products: a review, Atmos. Environ., 33, 1423-1439, 1998.

Canagaratna, A., Jayne, J. T., Jimenez, J.-L., Allan, J. D., Alfarra, M. R., Zhang, Q., Onasch, T. B., Drewnick, F., Coe, H., Middlebrook, A., Delia, A., Williams, L. R., Trimborn, A. M., Northway, M. J., DeCarlo, P. F., Kolb, C. E., Davidovits, P., and Worsnop, D.R.: Chemical and microphysical characterization of ambient aerosols with the AMS, Mass Spectrom. Rev., 26, 185222, 2007.

Dal Maso, M., Sogacheva, L., Aalto, P. P., Riipinen, I., Komppula, M., Tunved, P., Korhonen, L., Suur-Uski, V., Hirsikko, A., Kurtén, T., Kerminen, V.-M., Lihavainen, H., Viisanen, Y., Hansson, H.-C., and Kulmala, M.: Aerosol size distribution measurements at four Nordic field stations: identification, analysis and trajectory analysis of new particle formation bursts, Tellus, 59B, 350-361, 2007.

Donahue, N. M., Kroll, J. H., Pandis, S. N., and Robinson, A. L.: A two-dimensional volatility basis set - Part 2: Diagnostics of organic-aerosol evolution, Atmos. Chem. Phys., 12, 615-634, doi:10.5194/acp-12-615-2012, 2012.

Dunning Jr., T. H., Peterson, K. A., and Wilson, A. K.: Gaussian basis sets for use in correlated molecular calculations. X. The atoms aluminum through argon revisited, J. Chem. Phys., 114, 9244-9253, 2001.

Ehn, M., Vuollekoski, H., Petäjä, T., Kerminen, V.-M., Vana, M., Aalto, P., de Leeuw, G., Ceburnis, D., Dupuy, R., O’Dowd, C. D., and Kulmala, M.: Growth rates during coastal and marine new particle formation in Western Ireland, J. Geophys. Res., 115, D18218, doi:10.1029/2010JD014292, 2010.

Feyereisen, M., Fitzgerald, G., and Komornicki, A.: Use of Approximate integrals in ab initio theory. An application in MP2 energy calculations, Chem. Phys. Lett., 208, 359-363, 1993.

Glasius, M., Lahaniati, M., Calogirou, A., Di Bella, D., Jensen, N. R., Hjorth, J., Kotzias, D., and Larsen, B. R.: Carboxylic acids in secondary aerosol from oxidation of cyclic monoterpenes by ozone, Environ. Sci. Technol., 34, 1001-1010, 2000.

Hansen, J., Sato, M., Kharecha, P., and von Schuckmann, K.: Earth's energy imbalance and implications, Atmos. Chem. Phys., 11, 13421-13449, doi:10.5194/acp-11-13421-2011, 2011.

Hirsikko, A., Laakso, L., Hõrrak, U., Aalto, P. P., Kerminen, V.-M., and Kulmala M.: Annual and size dependent variation of growth rates and ion concentrations in boreal forest, Boreal Enviiron. Res., 10, 357-369, 2005.

Jokinen, V. and Mäkelä, J.: Closed loop arrangement with critical orifice for DMA sheath/excess flow system, J. Aerosol Sci., 28, 643-648, 1996.

Junninen, H., Hulkkonen, M., Riipinen, I., Nieminen, T., Hirsikko, A., Suni, T., Boy, M., Lee, S.-H., Vana, M., Tammet, H., Kerminen, V.-M., and Kulmala, M.: Observations on nocturnal growth of atmospheric clusters, Tellus, 60B, 365-371, 2008.

Kazil, J., Stier, P., Zhang, K., Quaas, J., Kinne, S., O’Donnell, D., Rast, S., Esch, M., Ferrachat, S., Lohmann, U., and Feichter, J.: Aerosol nucleation and its role for clouds and Earth's radiative forcing in the aerosol-climate model ECHAM5-HAM,
Atmos. Chem. Phys., 10, 10733-10752, doi:10.5194/acp-1010733-2010, 2010.

Kerminen, V.-M., Anttila, T., Petäjä, T., Laakso, L., Gagné, S., Lehtinen, K. E. J., and Kulmala, M.: Charging state of the atmospheric nucleation mode: Implications for separating neutral and ion-induced nucleation, J. Geophys. Res., 112, D21205, doi:10.1029/2007JD008649, 2007.

Kerminen, V.-M., Petäjä, T., Manninen, H. E., Paasonen, P., Nieminen, T., Sipilä, M., Junninen, H., Ehn, M., Gagné, S, Laakso, L., Riipinen, I., Vehkamäki, H., Kurtén, T., Ortega, I. K., Dal Maso, M., Brus, D., Hyvärinen, A., Lihavainen, H., Leppä, J., Lehtinen, K. E. J., Mirme, A., Mirme, S., Hõrrak, U., Berndt, T., Stratmann, F., Birmili, W., Wiedensohler, A., Metzger, A., Dommen, J., Baltensperger, U., Kiendler-Scharr, A., Mentel, T. F., Wildt, J., Winkler, P. M., Wagner, P. E., Petzold, A., Minikin, A., Plass-Dülmer, C., Pöschl, U., Laaksonen, A., and Kulmala, M.: Atmospheric nucleation: highlights of the EUCAARI project and future directions, Atmos. Chem. Phys., 10, 10829-10848, 2010, http://www.atmos-chem-phys.net/10/10829/2010/.

Korhonen, H., Lehtinen, K. E. J., and Kulmala, M.: Multicomponent aerosol dynamics model UHMA: model development and validation, Atmos. Chem. Phys., 4, 471-506, doi:10.5194/acp-4417-2004, 2004.

Kroll, J. H. and Seinfeld, J. H.: Chemistry of secondary organic aerosol: Formation and evolution of low-volatility organics in the atmosphere, Atmos. Environ., 42, 3593-3624, 2008.

Kulmala, M. and Kerminen, V.-M.: On the growth of atmospheric nanoparticles, Atmos. Res., 90, 132-150, 2008.

Kulmala, M., Vehkamäki, H., Petäjä, T., Dal Maso, M., Lauri, A., Kerminen V.-M., Birmili, W., and McMurry, P. H.: Formation and growth rates of ultrafine atmospheric particles: a review of observations, J. Aerosol. Sci., 35, 143-176, 2004.

Kulmala, M., Lehtinen, K. E. J., and Laaksonen, A.: Cluster activation theory as an explanation of the linear dependence between formation rate of $3 \mathrm{~nm}$ particles and sulphuric acid concentration, Atmos. Chem. Phys., 6, 787-793, doi:10.5194/acp-6-787-2006, 2006.

Kulmala, M., Riipinen, I., Sipilä, M., Manninen, H. E., Petäjä, T., Junninen, H., Dal Maso, M., Mordas, G., Mirme, A., Vana, M., Hirsikko, A., Laakso, L., Harrison, R. M., Hanson, I., Leung, C., Lehtinen, K. E. J., and Kerminen, V.-M.: Toward direct measurement of atmospheric nucleation, Science, 318, 89-92, 2007.

Lauros, J., Sogachev, A., Smolander, S., Vuollekoski, H., Sihto, S.L., Mammarella, I., Laakso, L., Rannik, Ü., and Boy, M.: Particle concentration and flux dynamics in the atmospheric boundary layer as the indicator of formation mechanism, Atmos. Chem. Phys., 11, 5591-5601, doi:10.5194/acp-11-5591-2011, 2011.

Lee, S.-H., Young, L.-H., Benson, D. R., Suni, T., Kulmala, M., Junninen, H., Campos, T. L., Rogers, D. C., and Jensen, J.: Observations of nighttime new particle formation in the troposphere, $\mathrm{J}$. Geophys. Res., 113, D10210, doi:10.1029/2007JD009351, 2008.

Leppä, J., Kerminen, V.-M., Laakso, L., Korhonen, H., Lehtinen, K. E. J., Gagne, S., Manninen, H. E., Nieminen, T., and Kulmala, M.: Ion-UHMA: a model for simulating the dynamics of neutral and charged aerosol particles, Boreal Environ. Res., 14, 559-575, 2009.

Makkonen, R., Asmi, A., Korhonen, H., Kokkola, H., Järvenoja, S., Räisänen, P., Lehtinen, K. E. J., Laaksonen, A., Kerminen, V.M., Järvinen, H., Lohmann, U., Bennartz, R., Feichter, J., and 
Kulmala, M.: Sensitivity of aerosol concentrations and cloud properties to nucleation and secondary organic distribution in ECHAM5-HAM global circulation model, Atmos. Chem. Phys., 9, 1747-1766, doi:10.5194/acp-9-1747-2009, 2009.

Manninen, H. E., Petäjä, T., Asmi, E., Riipinen, I., Nieminen, T., Mikkilä, J., Hõrrak, U., Mirme, A., Mirme, S., Laakso, L., Kerminen, V.-M., and Kulmala, M.: Long-term field measurements of charged and neutral clusters using Neutral cluster and Air Ion Spectrometer (NAIS), Boreal Environ. Res., 14, 591-605, 2009.

Manninen, H. E., Nieminen, T., Asmi, E., Gagné, S., Häkkinen, S., Lehtipalo, K., Aalto, P., Vana, M., Mirme, A., Mirme, S., Hõrrak, U., Plass-Dülmer, C., Stange, G., Kiss, G., Hoffer, A., Töro, N., Moermann, M., Henzing, B., de Leeuw, G., Brinkenberg, M., Kouvarakis, G.N., Bougiatioti, K., Mihalopoulos, N., O’Dowd, C., Ceburnis, D., Arneth, A., Svenningsson, B., Swietlicki, E., Tarozzi, L., Decesari, S., Facchini, M.C., Birmili, W., Sonntag, A., Wiedensohler, A., Boulon, J., Sellegri, K., Laj, P., Gysel, M., Bukowiecki, N., Weingartner, E., Laaksonen, A., Hamed, A., Joutsensaari, J., Petäjä, T., Kerminen, V.-M., and Kulmala, M.: EUCAARI ion spectrometer measurements at 12 European sites - analysis of new-particle formation events, Atmos. Chem. Phys., 10, 7907-7927, doi:10.5194/acp-10-7907-2010, 2010.

Metzger, A., Verheggen, B., Dommen, J., Duplissy, J., Prevot, A. S. H., Weingartner, E., Riipinen, I., Kulmala, M., Spracklen, D. V., Carslaw, K. S., and Baltensperger, U.: Evidence for the role of organics in aerosol particle formation under atmospheric conditions, P. Natl. Acad. Sci., 107, 6646-6651, 2010.

Miehlich, B., Savin, A., Stoll, H., and Preuss, H.: Results obtained with the correlation-energy density functionals of Becke and Lee, Yang and Parr, Chem. Phys. Lett., 157, 200-206, 1989.

Myhre, G.: Consistency between satellite-derived and modeled estimates of the direct aerosol effect, Science, 325, 187-190, 2009.

Ortega, I. K., Kurtén, T., Vehkamäki, H., and Kulmala, M.: The role of ammonia in sulphuric acid ion induced nucleation, Atmos. Chem. Phys., 8, 2859-2867, doi:10.5194/acp-8-2859-2008, 2008.

Ortega, I. K., Suni, T, Grönholm, T, Boy, M, Hakola, H., Hellen, H., Valmari, T., Arvela H., Vehkamäki, H., and Kulmala M.: Is eucalyptol the cause of nocturnal events observed in Australia, Boreal Environ. Res., 14, 606-615, 2009.

Paasonen, P., Nieminen, T., Asmi, E., Manninen, H. E., Petaja, T., Plass-Dulmer, C., Flentje, H., Birmili, W., Wiedensohler, A., Horrak, U., Metzger, A., Hamed, A., Laaksonen, A., Facchini, M. C., Kerminen V. M., and Kulmala, M.: On the roles of sulphuric acid and low-volatility organic vapours in the initial steps of atmospheric new particle formation, Atmos. Chem. Phys., 10, 11223-11242, doi:10.5194/acp-10-11223-2010, 2010.

Quaas J., Ming, Y. Menon, S., Takemura, T., Wang, M., Penner, J. E., Gettelman, A., Lohmann, U., Bellouin, N., Boucher, O., Sayer, A. M., Thomas, G. E., McComiskey, A., Feingold, G., Hoose, C., Kristjánsson, J. E., Liu, X., Balkanski, Y., Donner, L. J., Ginoux, P. A., Stier, P., Grandey, B., Feichter, J., Sednev, I., Bauer, S.E., Koch, D., Grainger, R. G., Kirkevåg, A., Iversen, T., Seland, Ø., Easter, R., Ghan, S. J., Rasch, P. J., Morrison, H., Lamarque, J.-F., Iacono, M. J., Kinne, S., and Schulz, M.: Aerosol indirect effects - general circulation model intercomparison and evaluation with satellite data, Atmos. Chem. Phys., 9, 8697-8717, doi:10.5194/acp-9-8697-2009, 2009.
Radhakrishnan, K. and Hindmarsh, A. C.: Description and Use of LSODE, the Livermore Solver for Ordinary Differential Equations, Lawrence Livermore National Laboratory report, UCRLID-113855, 1993.

Sandu, A. and Sanders, R.:Technical note: Simulating chemical systems in Fortran90 and Matlab with the Kinetic PreProcessor KPP-2.1, Atmos. Chem. Phys., 6, 187-195, doi:10.5194/acp-6187-2006, 2006.

Sandu, A., Verwer, J. G., Loon, M. V., Carmichael, G. R., Potra, F. A., and Dabdub, D.: Benchmarking stiff ode solvers for atmospheric chemistry problems - I. implicit vs. explicit, Atmos. Environ., 31, 3151-3166, 1997.

Sipilä, M., Berndt, T., Petäjä, T., Brus, D., Vanhanen, J., Stramann, F., Patokoski, J., Mauldin III, R. L., Hyvärinen, A.P., Lihavainen, H., and Kulmala, M.: The role of sulfuric acid in atmospheric nucleation, Science, 327, 1243-1246, doi:10.1126/science.1180315, 2010.

Soler, J. M., Artacho, E., Gale, J. D., Garcia, A., Junquera, J., Ordejon, P., and Sanchez-Portal, D.: The SIESTA method for ab initio order-N materials simulation, J. Phys-Condens. Mat., 14, 2745-2779, 2002.

Spracklen, D. V., Carslaw, K. S., Kulmala, M., Kerminen, V.-M., Mann, G. W., and Sihto, S.-L.: The contribution of boundary layer nucleation events to total particle concentrations on regional and global scales, Atmos. Chem. Phys. 6, 5631-5648, doi:10.5194/acp-6-5631-2006, 2006.

Suni, T., Kulmala, M., Hirsikko, A., Bergman, T., Laakso, L., Aalto, P. P., Leuning, R., Cleugh, H., Zegelin, S., Hughes, D., van Gorsel, E., Kitchen, M., Vana, M., Hõrrak, U., Mirme, S., Mirme, A., Sevanto, S., Twining, J., and Tadros, C.: Formation and characteristics of ions and charged aerosol particles in a native Australian Eucalypt forest, Atmos. Chem. Phys., 8, 129-139, doi:10.5194/acp-8-129-2008, 2008.

Svenningsson, B., Arneth A., Hayward, S., Holst T., Massling A., Swietlicki E., Hirsikko, A., Junninen, H., Riipinen I', , Vana, M., Dal Maso, M., Hussein, T., and Kulmala, M.: Aerosol particle formation events and analysis of high growth rates observed above a subarctic wetland-forest mosaic, Tellus, 60B, 353-364, 2008.

Vehkamäki, H., Dal Maso, M., Hussein, T., Flanagan, R., Hyvärinen, A., Lauros, J., Merikanto, J., Mönkkönen, P., Pihlatie, M., Salminen, K., Sogacheva, L., Thum, T., Ruuskanen, T. M., Keronen, P., Aalto, P. P., Hari, P., Lehtinen, K. E. J., Rannik, Ü. and Kulmala, M.: Atmospheric particle formation events at Värriö measurement station in Finnish Lapland 1998-2002. Atmos. Phys. Chem. 4, 2015-2023, doi:10.5194/acp-4-2015-2004, 2004.

Wavefunction, Inc.: Spartan '06 Windows, Wavefunction, Inc. Irvine, CA, USA, http://wavefun.com, 2006.

Wiedensohler, A., Hansson, H.-C., Orsini, D., Wendisch, M., Wagner, F., and co-authors: Night-time formation and occurrence of new particles associated with orographic clouds, Atmos. Environ., 31, 2545-2559, 1997.

Yu, F., Luo, G., Bates, T. S., Anderson, T., Clarke, A., Kapustin, V., Yantosca, R. M., Wang, Y., and Wu, S.: Spatial distributions of particle number concentrations in the global troposphere: Simulations, observations, and implications for nucleation mechanisms, J. Geophys. Res., 115, D17205, doi:10.1029/2009JD013473, 2010. 